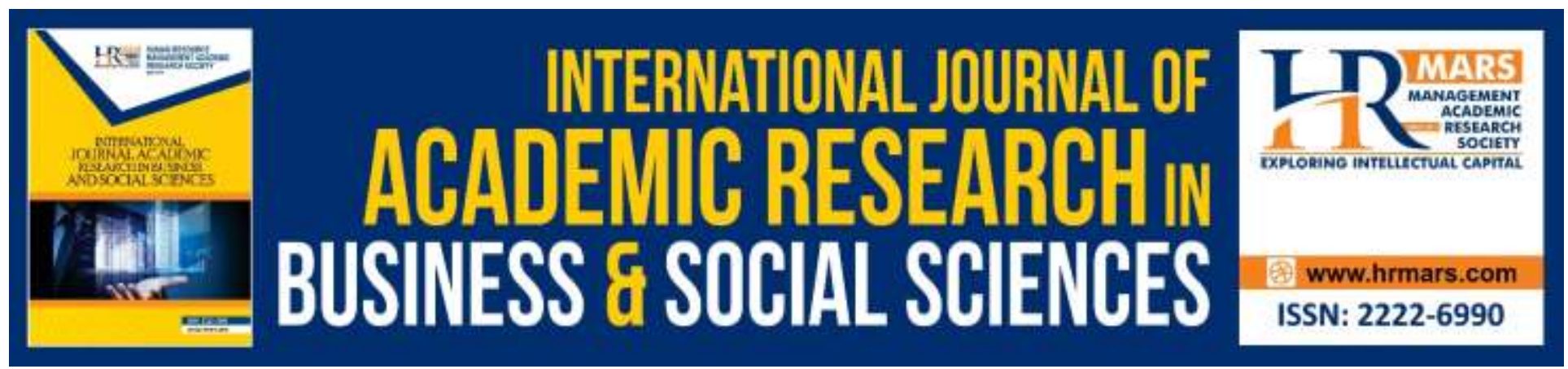

\title{
An Exploration of the Relationship between Organizational Culture and Turnover Intentions of Selected Small and Medium Enterprises (SMEs) in South-East
}

Mbah, Paulinus Chigozie, Ekechukwu, Chijioke, Obi, Irenausnna Emeka

To Link this Article: http://dx.doi.org/10.6007/IJARBSS/v8-i5/4158 DOI:10.6007/IJARBSS/v8-i5/4158

Received: 03 April 2018, Revised: 25 April 2018, Accepted: 05 May 2018

Published Online: 28 May 2018

In-Text Citation: (Mbah, Ekechukwu, \& Obi, 2018)

To Cite this Article: Mbah, P. C., Ekechukwu, C., \& Obi, I. E. (2018). An Exploration of the Relationship between Organizational Culture and Turnover Intentions of Selected Small and Medium Enterprises (SMEs) in SouthEast. International Journal of Academic Research in Business and Social Sciences, 8(5), 563-584.

Copyright: (C) 2018 The Author(s)

Published by Human Resource Management Academic Research Society (www.hrmars.com)

This article is published under the Creative Commons Attribution (CC BY 4.0) license. Anyone may reproduce, distribute, translate and create derivative works of this article (for both commercial and non-commercial purposes), subject to full attribution to the original publication and authors. The full terms of this license may be seen

at: http://creativecommons.org/licences/by/4.0/legalcode

Vol. 8, No. 5, May 2018, Pg. 563 - 584 


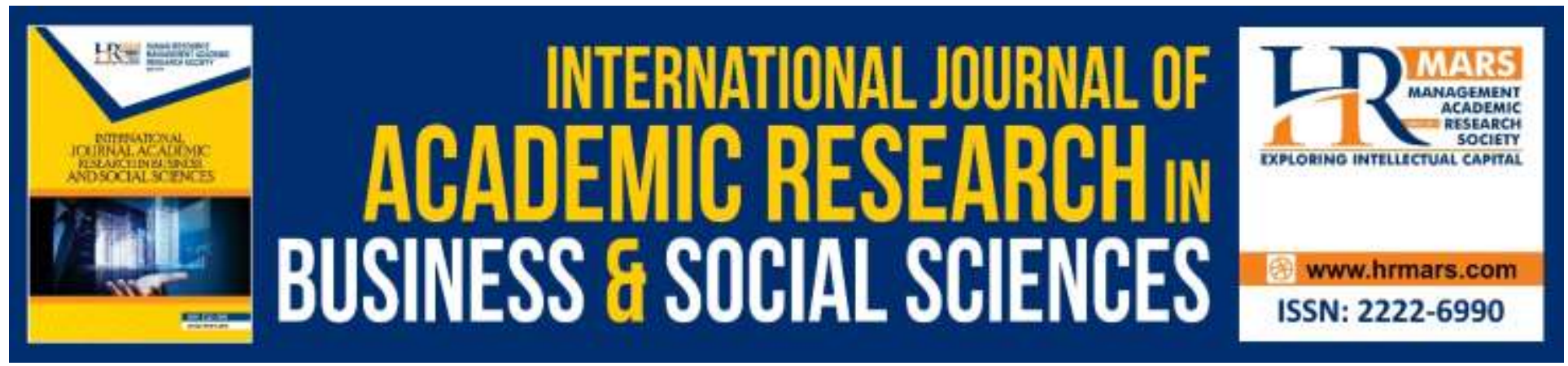

\title{
An Exploration of the Relationship between Organizational Culture and Turnover Intentions of Selected Small and Medium Enterprises (SMEs) in South-East
}

\author{
Mbah, Paulinus Chigozie \\ Department of Business Administration, Faculty of Management Sciences \\ Enugu State University of Science and Technology (ESUT) Enugu, Nigeria \\ Email: godblesspaulinus@yahoo.com \\ Ekechukwu, Chijioke \\ Department of Banking and Finance, Faculty of Management Sciences \\ Enugu State University of Science and Technology (ESUT) Enugu, Nigeria \\ Email: Chijioke.bristol@yahoo.com \\ Obi, Irenausnna Emeka \\ Department of Business Administration, Faculty of Management Sciences \\ Enugu State University of Science and Technology (ESUT) Enugu, Nigeria \\ Email: Igweobi2015@yahoo.com
}

\begin{abstract}
This study explores the Relationship between Organizational Culture and Turnover Intentions of selected Small and Medium Enterprises in Southeast - Nigeria. Specifically,it investigates the effects of founder's values on the turnover intentions of SMEs; socialization on the employee turnover intentions; and morale on turnover intentions of SMEs. Survey method of data gathering was adopted wherein structured questionnaire was instrument of data collection. With a population of 2500 registered SMEs within the capitals of the five South-eastern States, a sample size of 330 was drawn using Freud and William's formula at 5\% error margin. 330 copies of questionnaire were distributed while 300 were returned. Three hypotheses were tested using the component of t-test in the Statistical Package for Social Science (SPSS). Results of the analysis reveal that Founder's value has positive impact on the turnover intention of small and medium scale enterprise, $\chi^{2}(95, n=330)=11.32036, p<0.05$.; Socialization have positive impact on the Turnover Intention, $\chi^{2}(95, \mathrm{n}=330)=9.133469, \mathrm{p}<0.05$; while morale have no effect on turnover intention, $\chi^{2}(95, n=330)=0.337944 p>0.05$. The study concludes that organizational culture
\end{abstract}


INTERNATIONAL JOURNAL OF ACADEMIC RESEARCH IN BUSINESS AND SOCIAL SCIENCES

Vol. 8, No. 5, May 2018, E-ISSN: 2222-6990 @ 2018 HRMARS

has strong correlation with turnover intension. Therefore, it recommends employee motivational administrative strategies for higher profit generation.

Keywords: Organizational Culture, Turnover Intentions, SMEs, Employee, Higher Profit.

\section{Introduction}

The Small and Medium Enterprises (SMEs) seems to be recording higher growth rate as compared to other industrial sectors across the world. Small and Medium Enterprise as used here is viewed in terms of enterprises annual turnover of capital and the number of its paid employees (Ekpeyong and Nyang, 2012). From this perspective, the Central Bank of Nigeria in its monetary policies circular No. 22 of 1988 views small scale industry as those enterprise which has annual turnover not exceeding (N500,000) five hundred thousand naira. The sector is basically noted for its employment potential, low capital cost or investment requirements, and while it's labour intensity is estimated to be higher than other industrial sectors.

Previous researches such as Ayyagari et al. (2011), Hurst and Pungsley (2011), Miliaras (2012), and Gonzales (2013) among others demonstrate that enabling business environment, which include good organizational culture enables the growth of SMEs. Alvesson (2002) and Kunda and Maanen (1989) noted that organizational cultural dynamics influence the way people think, feel and act, in this case, during production or business processes. It motivates employees, influence their thoughts, decision-making and resource allocation processes, and facilitates communication.

Organizational culture provides a framework with respect to the behavior of employees in their workplace. However, its ability to propel growth depends on the type of culture created in an organization. Thus, organizational culture can exhibit positive or negative impact on workers' motivation and performance. Performance as used here refers to the extent an individual carries out an assignment/task or the degree of accomplishment of one's task or responsibility as an employee (Cascio, 2006). Qazi, Miralam, and Bhalla (2017, p, 215) captured this opinion thus;

Culture can support linkages between technology adoption and organizational growth; it can be a critical success factor in organization growth strategy and play

a crucial role in determining the success or failure of organization.

Nazneen et al (2014) identified the most dominant components of such culture in organized SMEs as confrontation, openness, experimentation and proactive response to tasks among others. However, it is hard to determine an appropriate and unified culture for all SMEs because they differ in character, external environment relations, while their situational constraints, which dictate or structure different values, beliefs and behaviors for them, differ (Muzainah and Mahamad, 2010).

Each of the SMEs needs to appreciate its own culture with a view to adopt the best administrative strategy for enhanced organizational growth, which must consider the foundational intentions of the enterprise. For instance, in most of the Nigerian cultures like the Yoruba, Ibo, and Hausa among others, women are not engaged in occupations that will take them outside their matrimonial home. They are family administrators who are obliged to "be submissive to their husbands'. Therefore cultures such as marriage culture, energy supply culture, the culture of trade unionism, trading and finance cultures, person/individual culture of the employees, task 
culture, which is job or project oriented, authority culture, employment culture, and profit maximization culture among others define the position of the turnover intentions of SMEs.

Enterprises Turnover Intention as used here refers to employee's plans to leave or resign from their jobs or to be fired by the employees. It is voluntary when one resigns in the organizations and involuntary when the organization decides to sack the employees. As Small and Medium scale enterprises have being a veritable instrument for economic growth and development in most parts of the world including Nigeria, it becomes plausible to explore the relationship between organizational culture and turnover intentions in selected Small and Medium Enterprises in South-East Nigeria. Stein et al. (2010) observed that SMEs holds approximately $45 \%$ of employment and approximately $33 \%$ of GDP in the less developing Countries (LDCs). OECD (2004) findings, which noted that SMEs provide $60-70 \%$ of employment while accounting $55 \%$ of the GDP in LDCs corroborated this. The investigation and choice of South-east Nigeria is timely as the SMEs dominate business and industrial development in the region, yet development in the region is highly retarded.

\section{Statement of the Problem}

With the latest global economic recession of 2008, the private sector particularly the SMEs are faced with the policy of downsizing their workforce thereby increasing the degree of unemployment in Nigeria geometrically. The consequences of this scenario have being underemployment, exploitation of workers by employers of labor knowing that many others are in cue to be employed; termination of people's employment at will, and massive resignation on the part of workers when better opportunity present itself. It is a possibility that those dismissed or who resigned from the organization maybe endowed with talents and/or skills more those remaining in the organization. This leads to deteriorating organizational efficiency, and fall in the growth rate of the enterprise.

\section{The Objectives of the Study}

The main objective of the study is to explore the relationship between organizational culture and turnover intentions of Selected Small and Medium Enterprises in South-East, Nigeria. However, its specific objectives include to:

i. Assess the effect of founder values on the turnover intentions of SMEsin South-east Nigeria.

ii. Ascertain if socialization has any influence on the employee turnover intentions in Southeast Nigeria SMEs.

iii. Ascertain the extent that morale affects the turnover intentions of SMEs in South-east Nigeria.

\section{Research Questions}

In pursuit of the above objectives, this inquiry seeks answers to the following questions:

i. Has founder's valueany impact on the turnover intentions of SMEs in South-east Nigeria?

ii. Has socialization any influence on the employee turnover intentions in South-east Nigeria SMEs?

iii. To what extent does morale affect the turnover intentions of SMEs? 
INTERNATIONAL JOURNAL OF ACADEMIC RESEARCH IN BUSINESS AND SOCIAL SCIENCES

Vol. 8, No. 5, May 2018, E-ISSN: 2222-6990 @ 2018 HRMARS

\section{Research Hypotheses}

The research is poised to test the following hypotheses:

i. Founder's values have great positive impact on the turnover intentions of SMEsin Southeast Nigeria.

ii. Socialization exhibits positive influence on the employee turnover intentions in South-east Nigeria SMEs.

iii. Morale has significant positive effect on the turnover intentions of SMEsin South-east Nigeria SMEs

\section{Review of Extant Literature and Framework of Analysis}

This paper presents the result of its literature review in three major headings, namely: conceptual review, theoretical framework, and empirical review. A summary at the end highlights the academic gap found in the literature, which the paper attempts to fill.

\section{Conceptual Framework}

\section{Small and Medium Enterprises (SMEs)}

There is no evidence of generally accepted definition of Small and Medium Enterprises (SMEs) in the literature (Gibson, and Van der Vaart, 2008).Nevertheless, majority of the existing definitions of SMEs were characterized by quantitative factors such as total assets, and number of workers, and sales as indices that differentiate SMEs from other enterprises in the industrial sector (see Kushnir, Mirmulstein, and Ramalho, 2010). Scholars like Ayyagari, Beck, and Demirgüç-Kunt (2007); Kushnir et al. (2010) defined SMEs as enterprises with 250 workers in its employ.

Nevertheless, different authors, scholars, and schools have different ideas as to the differences in capital outlay, number of employees, sales turnover, fixed capital investment, available plant and machinery, market share and the level of development, these features equally vary from one country to the other. In Nigeria, the Third National Development plan (2014) defined small and medium enterprises as a manufacturing establishment employing less than ten people, or whose investment in machinery and equipment does not exceed six hundred thousand naira. There are many enterprises in Nigeria categorized as SMEs. Most of them are in the commercial sector and there is also a trend now towards the services industry sector like hotels, restaurants, fast foods, etc.

\section{Organization Culture}

Alvesson (2002, p. 10) observed that "Culture is thus highly significant for how companies and other organizations function; from strategic change, to everyday leadership and how managers and employees relate to and interact with customers as well as to how knowledge is created, shared, maintained and utilized." Such culture is called organization culture. It enables workers to explain many puzzling and frustrating experiences in their social and organizational life; and to understand themselves better (Schein, 2010). Further, it is shield against individual frustrations in their workplaces because it enables them to understand, explain, and encounter irrational or unfamiliar behavior from people in their organizations and everyday life.

Therefore most scholars simply define organization culture in the light of Schein $(1984$, p. 6) as:

...the pattern of basic assumptions that a given group

has invented, discovered, or developed in learning to 
cope with its problems of external adaption and internal integration, and that have worked well enough to be considered valid, and, therefore, to be taught to new members as the correct way to perceive, think, and feel in relation to those problems (Schein, 1984, p. 3).

This definition was modifies or modernized by Edgar H. Schien in 2010 thus:

The culture of a group can now be defined as a pattern of shared basic assumptions learned by a group as it solved its problems of external adaptation and internal integration, which has worked well enough to be considered valid and, therefore, to be taught to new members as the correct way to perceive, think, and feel in relation to those problems (Schein, 2010, p. 18).

Similarly, Ezigbo (2011) defined organizational culture as the specific collection of values and norms that are shared by people and groups in an organization, which defines and control the way they interact with each other and with stakeholder to achieve corporate and individual goals. Organizational values are beliefs and ideas about what kinds of goals members of an organization should pursue and ideas about the appropriate kinds or standards of behaviour organizational members should use to achieve these goals. The values and norms that are the basis of culture are formed by the leaders in the organization, especially those who have shaped it in the past.

\section{Turnover Intention}

Turnover is the process through which staff leaves an enterprise or organization and that business or organization replaces them. Turnover intention is a measurement of employees plan to leave their positions/organization or organization's plans to remove employees from their positions and replace them. Turnover intention, like turnover itself, can be either voluntary or involuntary Michaele (2017). Employees who leave on the organization's request as well as those who leave on their own initiative can cause disruptions in operations, work team dynamics and unit performance. Both types of the turnover create costs for the organization. If an organization has made significant investment in training and developing its employees, that investment is lost when employee leaves (Mello, 2011). Employee turnover is an important factor in a small business's bottom line. Replacing employees can affect a business' productivity, expenses and overall performance. If you can measure your staff's turnover intention, you can determine the likelihood of your staff leaving your organization. This helps you determine where you can find opportunities to reduce your overall turnover.

\section{Theoretical Framework}

One of the major theories of culture-institution's relationship is Cultural evolution theory. The theory holds that traits have certain meanings in the context of evolutionary stages and therefore classify cultures according to their relative degree of social complexity. It employs several economic distinctions (foraging, hunting, farming, and industrial societies) or political distinctions (autonomous villages, chiefdoms, and states) in explaining these social complexities. According to Hein (2008), the theory investigates the relationships between material culture and social institutions and beliefs. 
Critics of this theory argue that the use of evolution as an explanatory metaphor is flawed, because it tends to assume a certain direction of development, with an implicit apex at modern, industrial society. Ecological approaches explain the different ways that people live around the world not in terms of their degree of evolution but rather as distinct adaptations to the variety of environments in which they live. They also demonstrate how ecological factors may lead to cultural change, such as the development of technological means to harness the environment. Structural-functionalists posit society as an integration of institutions (such as family and government), defining culture as a system of normative beliefs that reinforces social institutions. Some criticize this view, which suggests that societies are naturally stable. Historical-particularists look upon each culture as a unique result of its own historical processes. Symbolic anthropology looks at how people's mental constructs guide their lives.

Another major theoretical construct used in the study, comprehension and prediction of the relationship is the Structural theory. The theory analyses the relationships among cultural constructs of different societies, deriving universal mental patterns and processes from the abstract models of these relationships. They theorize that such patterns exist independent of, and often at odds with, practical behavior. Many theories of culture have been criticized for assuming, intentionally or otherwise, that all people in any one society experience their culture in the same way. Today, many anthropologists view social order as a fragile accomplishment that various members of a society work at explaining, enforcing, exploiting, or resisting. They have turned away from the notion of elusive "laws" of culture that often characterizes cross-cultural analyses to the study of the concrete historical, political, and economic forces that structure the relations among cultures.

\section{Previous Studies}

\section{The Effect of Founders Value on the Turnover Intention of SME}

Swati (2016) investigated the effects of transformational leadership on turnover intentions in IT SMEs with a view to find out the impact of transformational leadership (TL) on building trust and hence, its influence on the commitment level of the employees to achieve the desired work outcomes. It also examined whether transformational leaders were able to psychologically empower employees so as to increase their commitment level and thus reduce the employee turnover intentions (TIs) in the small- and medium-sized (SME) IT companies operating in Delhi NCR, India. Survey research and a sample of 420 employees (168 females and 252 males) were adopted while questionnaire was the instrument used to collect data.

The analysis of data reveals that transformational leaders were able to create a higher level of PE and trust amongst their employees; and an increase in their commitment level, which led to a decrease in their TI. The findings suggest that trust, commitment and PE act as mediators. Limited sample size is a possible limitation of the study. One more limitation of the study is the data collection method, i.e. through survey. It was self-reported, taking only the perspective of the employees; it may not be a completely accurate response. With TL, leaders can psychologically empower followers to do things in a better way and can develop trust in employees resulting in high commitment; highly committed employees in turn reduce the TIs. If followers do not have faith in their own capability, it may not be possible for them to complete their job effectively. This study adds to the existing literature; it clarifies the process by which transformational leaders enhance followers' meaning in life through PE and develop trust resulting in high commitment. 
INTERNATIONAL JOURNAL OF ACADEMIC RESEARCH IN BUSINESS AND SOCIAL SCIENCES

Vol. 8, No. 5, May 2018, E-ISSN: 2222-6990 @ 2018 HRMARS

Chu and Chieh (2016) investigated the impact of corporate ethical values on turnover intention. Their analysis of data reveals that career satisfaction directly relates to turnover intention whereas corporate ethical values indirectly relate to turnover intention through the full mediation of organizational identification. Meanwhile, the effects of career satisfaction on turnover intention and on organizational identification are positively moderated by corporate ethical values. Last, managerial implications and research limitations are discussed.

\section{The Effect of Socialization on the Employee Turnover Intentions}

Mariam and Hummayoun (2011) studied the relationship of organization socialization with organizational commitment and turnover intention. The study investigated the impact of organizational socialization on organizational commitment and turnover intention with moderating role of perceived organizational support. Field survey approach was adopted to collect data from 310 employees selected from the telecom sector in Pakistan using questionnaire as instrument of data collection. Analysis of the data generated reveals that organizational socialization enhances organizational commitment of employees, thus reducing cost of losing employees. Therefore, it recommended the modernization or re-designing of socialization program to boast the expectation of employees.

Sabri et al (2011) investigated the effect of organizational culture on job satisfaction level of teachers of public and private sector higher education institutes and universities of Lahore which is second largest city of Pakistan and a hub of higher education using a sample of 347 teachers. The findings of the research reveal that organizational culture is categorized into two components i.e. organizational culture related to managers and leaders (OCM) and organizational culture related to employees (OCE). In this study effect of both kinds of culture on job satisfaction is positive and significant

Tsai (2011) studied Job satisfaction, organization culture and leadership behavior among nurses in Taiwan using a sample of 200 nurses. Analysis of data reveals that there is a positive significant relationship between organization culture and job satisfaction. It further reveals that job satisfaction level among nurses is high and they endorse the culture as positive. Similarly, Shah (2011) studied the impact of organizational culture on employee's job satisfaction of university faculty in Public Sector in Pakistan using a sample of 215 respondents. Result of analysis reveals that there is a negative relationship between organizational culture and employees' job satisfaction. The study recommended an improvement of the working efficiency of the faculty members in public sector universities in Pakistan.

Bake and Nalla (2009) investigated the relationship between organizational culture and job satisfaction among police officers in two Midwestern states in United States. Survey method, questionnaire, and a sample of 669 respondents were adopted for data gathering. Analysis of data shows that organizational characteristics are better predictors of job satisfaction than individual factors. Similarly, Askari (2011) investigated the relationship between organizational culture and job stress of personnel in government departments at Firozabad city. Analysis of data reveals a high level negative relationship between organizational culture and job stress. It further reveals differences in the impact of organizational culture among men and women. 


\section{The Extent Morals Affect the Turnover Intention of SMEs}

Obiwuru, Okwu, Akpa and Nwankwere (2011) investigated the effects of leadership style on organizational performance among selected small scale enterprises in Ikosi-Ketu council development area of Lagos State, Nigeria. Survey design and employed evaluative quantitative analysis method were adopted to analyse primary data generated through a structured Multifactor Leadership Questionnaire (MLQ) administered on respondents. Analysis results show that there is a significant positive effect of transactional leadership on performance; transformational leadership style has positive but insignificant effect on performance. The study recommended transactional leadership style for SMEs with inbuilt strategies for transition to transformational leadership style.

Raheleh, Ebrahim, Durrishah, Dhaifallah, (2012) studied the relationship between organizational learning culture, Job satisfaction and turnover Intention in SMEs using IT companies in Iran. The study adopted descriptive, co-relational and cross-sectional method of data gathering. With questionnaires, data was collected from a sample of 132 employees through a simple random sampling method and analysed using Correlation analysis. Analysis results reveal a significant and moderate positive correlation among the seven dimensions of organizational learning culture and job satisfaction; negative relationship between the seven dimensions of organizational learning culture and turnover intention; and strong negative relationship between Job satisfaction and turnover intention.

A summary of the literature shows that scholars have investigated the thematic focus of the present research; however, most of the inquiries were carried out in other sectors that have different environment, goals, and processes from SMEs. The studies were equally carried out in countries outside Africa and Nigeria that possess different developmental experiences and sociocultural orientations. Therefore, this paper investigates the phenomenon in South-east Nigeria and in SMEs with a view to determine the applicability of previous findings and to explore areas not covered adequately by former researchers.

\section{Methodology \\ Research Design}

This paper adopted survey method of data gathering due to wide expanses of land and population dispersion across the five states of the South-East Nigeria. The specific group of SMEs for study in these states are cottage industries, provision stores, pharmaceutical companies, poultry farmers and engine oil producers. Structured and closed-ended questionnaire was adopted as the primary instrument of data collection in addition to secondary sources. The validity of the questionnaire instrument used was tested by experts in the Faculties of Management Science, University of Nigeria (Enugu Campus) who were asked to assess the relevance of the content of the tool and to ensure its potency. On the other hand, the reliability was tested using the Pearson correlation coefficient ( $r$ ). It gave a reliability co-efficient of 0.92 which was also good.

\section{Population and Sample of the Study}

The population of study consists of 2,500 small and medium enterprises comprising cottage industries, provision stores, pharmaceutical companies, poultry farmers and engine oil producers randomly selected from the capital territories of the five states of South-East Nigeria. With the 
INTERNATIONAL JOURNAL OF ACADEMIC RESEARCH IN BUSINESS AND SOCIAL SCIENCES

Vol. 8, No. 5, May 2018, E-ISSN: 2222-6990 ㄷ 2018 HRMARS

aid of Freund and William's formula for the determining sample size, 330 staff was sampled. However, only a total of 300respondents accurately filled and returned the questionnaire. This represents $91 \%$ response rate.

\section{Method of Data Analysis}

The data generated with the aid of questionnaire were analyzed using t-test statistical tool provided by the Special package of statistical Software (SPSS).

Data Presentation and Test of Hypotheses

Presentation of data: Table i: Distribution and Return of Questionnaire

\begin{tabular}{lccccc}
\hline SMEs & $\begin{array}{l}\text { questionnaire } \\
\text { distributed }\end{array}$ & $\begin{array}{c}\text { Questionnaire } \\
\text { returned }\end{array}$ & \% returned & $\begin{array}{c}\text { No not } \\
\text { returned }\end{array}$ & $\begin{array}{c}\text { \% not } \\
\text { returned }\end{array}$ \\
\hline Cottage industries & 73 & 69 & 21 & 4 & 1 \\
Super markets & 70 & 67 & 20 & 3 & 1 \\
Pharm. Co & 30 & 27 & 8 & 3 & 1 \\
Poultry farms & 48 & 41 & 2 & 7 & 2 \\
Engine oil producers & 57 & 48 & 15 & 9 & 3 \\
Transport co & 52 & 48 & 15 & 4 & 1 \\
Total & 330 & 300 & 91 & 30 & 9 \\
\hline
\end{tabular}

Source: Field survey 2017

Table ' $i$ ' above shows that 300 respondents of small and medium enterprise representing $91 \%$ accurately filled and returned their questionnaire, while 30 respondents representing $9 \%$ did not return their questionnaire and was not used.

Table ii: Response on the effect of founders values on the turnover intention of small and medium enterprise.

\begin{tabular}{lcccccccc}
\hline Options & $\begin{array}{l}\text { Cottage } \\
\text { ind. }\end{array}$ & $\begin{array}{l}\text { Supermkts/ } \\
\text { Provision }\end{array}$ & $\begin{array}{l}\text { Pharm. } \\
\text { Co }\end{array}$ & $\begin{array}{l}\text { Poultry } \\
\text { farmer }\end{array}$ & $\begin{array}{l}\text { Engine } \\
\text { producers }\end{array}$ & $\begin{array}{l}\text { Transport } \\
\text { co. }\end{array}$ & $\begin{array}{l}\text { Total } \\
\text { Per } \\
\text { cent }\end{array}$ \\
\hline Strong & 31 & 27 & 7 & 24 & 29 & 26 & 144 & 48 \\
agree & & & & & & & & \\
Agree & 21 & 27 & 16 & 5 & 1 & 15 & 100 & 33 \\
Neutral & 6 & 3 & 2 & 7 & 1 & 2 & 21 & 7 \\
Disagree & 2 & 5 & 1 & 4 & 1 & 2 & 15 & 5 \\
Strongly & 9 & 5 & 1 & 1 & 1 & 3 & 20 & 7 \\
disagree & & & & & & & & \\
Total & 69 & 67 & 27 & 41 & 48 & 48 & 300 & 100 \\
\hline
\end{tabular}

Source: field survey 2017.

Table 'ii' shows that 144 respondents out of 300 representing 48\% strongly agree;and 100 respondents(33.3\%) agree that founders' values affect the turnover intentions of small and medium enterprises; 21 respondents (7\%) were neutral, 15 respondents (5\%) disagree, while 20 respondents ( $7 \%$ ) strongly disagree. The implication is that there is effect of founders' value on turnover intention of small and medium enterprise. 
INTERNATIONAL JOURNAL OF ACADEMIC RESEARCH IN BUSINESS AND SOCIAL SCIENCES

Vol. 8, No. 5, May 2018, E-ISSN: 2222-6990 @ 2018 HRMARS

Table III: Response on the socialization effect on the turnover intention of small and medium enterprise

\begin{tabular}{lcccccccc}
\hline Options & $\begin{array}{l}\text { Cottage } \\
\text { Inds. }\end{array}$ & $\begin{array}{l}\text { Super } \\
\text { mkts./ } \\
\text { Provision }\end{array}$ & $\begin{array}{l}\text { Pharm. } \\
\text { Co }\end{array}$ & $\begin{array}{l}\text { Poultry } \\
\text { farmer }\end{array}$ & $\begin{array}{l}\text { Engine } \\
\text { producers }\end{array}$ & $\begin{array}{l}\text { Transport } \\
\text { co. }\end{array}$ & $\begin{array}{l}\text { Total } \\
\text { Per } \\
\text { cent }\end{array}$ \\
\hline Strong agree & 23 & 18 & 19 & 16 & 18 & 24 & 118 & 39 \\
Agree & 23 & 31 & 3 & 16 & 14 & 15 & 102 & 34 \\
Neutral & 7 & 8 & 3 & 4 & 2 & 1 & 25 & 8 \\
Disagree & 9 & 5 & 1 & 2 & 2 & 1 & 20 & 7 \\
Strongly & 7 & 5 & 1 & 3 & 12 & 7 & 35 & 12 \\
disagree & & & & & & & & \\
Total & 69 & 67 & 27 & 41 & 48 & 48 & 300 & 100 \\
\hline
\end{tabular}

Source: field survey 2017.

From the table 'iii' above, 118 respondents out of 300, representing 39\% strongly agree; and 102 respondents representing 34\% agree that socialization affects the turnover intention of small and medium enterprises. 25 respondents (8\%) were neutral; 20 respondents (7\%) disagree, while 35 respondents representing $12 \%$ strongly disagreed. This indicates that socialization affects the turnover intentions of small and medium enterprise.

Table IV: Response on the effect of Morals on Turnover Intention of Small and Medium Enterprises

\begin{tabular}{lcccccccc}
\hline Options & $\begin{array}{l}\text { Cottage } \\
\text { ind. }\end{array}$ & $\begin{array}{l}\text { Super } \\
\text { mkts/ } \\
\text { Provision }\end{array}$ & $\begin{array}{l}\text { Pharm. } \\
\text { Co }\end{array}$ & $\begin{array}{l}\text { Poultry } \\
\text { farmer }\end{array}$ & $\begin{array}{l}\text { Engine } \\
\text { producers }\end{array}$ & $\begin{array}{l}\text { Transport } \\
\text { co. }\end{array}$ & $\begin{array}{l}\text { Total } \\
\text { Per } \\
\text { cent }\end{array}$ \\
\hline Strong agree & 18 & 27 & 8 & 12 & 18 & 17 & 100 & 33 \\
Agree & 27 & 30 & 15 & 21 & 18 & 19 & 130 & 43 \\
Neutral & 7 & 5 & 1 & 5 & 4 & 7 & 29 & 10 \\
Disagree & 10 & 3 & 1 & 2 & 4 & 3 & 23 & 8 \\
Strongly & 7 & 2 & 2 & 1 & 4 & 2 & 18 & 6 \\
disagree & & & & & & & & \\
Total & 69 & 67 & 27 & 41 & 48 & 48 & 300 & 100 \\
\hline
\end{tabular}

Source: field survey 2017.

Table 'iv' above shows that 100 respondents out of 300 representing 33\% strongly agree; and 130 respondents (43\%) agree that Morales affects turnover intentions of small and medium enterprises. 29 respondents (10\%) were neutral, 23 respondents (8\%) disagree, while 18 respondents $(6 \%)$ strongly disagree that morals affects turnover intentions of SMEs. This implies that morals affects turnover intention in small and medium enterprise in South-East Nigeria. Each of us has a unique personality -traits and characteristics that influence the way we act and interact with others. When we describe someone as warm, open, relaxed, shy, or aggressive, we are describing personality traits. An organization, too, has a personality, which we call its culture (Stephen and Coulter, 2009). 
INTERNATIONAL JOURNAL OF ACADEMIC RESEARCH IN BUSINESS AND SOCIAL SCIENCES

Vol. 8, No. 5, May 2018, E-ISSN: 2222-6990 ㄷ 2018 HRMARS

\section{Test of Hypotheses}

The Microsoft assisted package-SPSS were used to test the three hypotheses. T-test was the statistical tool used to test the hypotheses. The compute hypotheses were presented as follows:

Hypothesis One: Founder's values have great positive impact on the turnover intentions of SMEs in South-east Nigeria.

Tables V: Summary Output

\begin{tabular}{|l|l|}
\hline \multicolumn{2}{|l|}{ Regression Statistics } \\
\hline \multicolumn{2}{|l|}{} \\
\hline Multiple R & 0.921875 \\
\hline R Square & 0.849854 \\
\hline Adjusted R Square & 0.774781 \\
\hline Standard Error & 21.98682 \\
\hline Regression Statistics \\
\hline Multiple R \\
\hline R Square & 0.921875 \\
\hline Adjusted R Square & 0.849854 \\
\hline Standard Error & 0.774781 \\
\hline
\end{tabular}

ANOVA

\begin{tabular}{|c|c|c|c|c|c|c|c|c|}
\hline & $D f$ & SS & MS & $F$ & $\begin{array}{l}\text { Significan } \\
\text { ce F }\end{array}$ & & & \\
\hline $\begin{array}{l}\text { Regressi } \\
\text { on }\end{array}$ & 3 & $\begin{array}{l}16417 . \\
48\end{array}$ & $\begin{array}{l}5472.4 \\
92\end{array}$ & $\begin{array}{l}11.320 \\
36\end{array}$ & 0.006974 & & & \\
\hline Residual & 6 & $\begin{array}{l}2900.5 \\
23\end{array}$ & $\begin{array}{l}483.42 \\
04\end{array}$ & & & & & \\
\hline \multirow[t]{2}{*}{ Total } & 9 & 19318 & & & & & & \\
\hline & $\begin{array}{l}\text { Coefficie } \\
\text { nts }\end{array}$ & $\begin{array}{l}\text { Standar } \\
d \text { Error }\end{array}$ & t Stat & $P$-value & $\begin{array}{l}\text { Lower } \\
95 \%\end{array}$ & $\begin{array}{l}\text { Upper } \\
95 \%\end{array}$ & $\begin{array}{l}\text { Lower } \\
95.0 \%\end{array}$ & $\begin{array}{l}\text { Upper } \\
95.0 \%\end{array}$ \\
\hline $\begin{array}{l}\text { Intercep } \\
t\end{array}$ & 50.3348 & $\begin{array}{l}23.666 \\
89\end{array}$ & 2.1268 & $\begin{array}{l}0.0775 \\
51\end{array}$ & -108.246 & $\begin{array}{l}7.5760 \\
33\end{array}$ & $\begin{array}{l}- \\
108.24 \\
6\end{array}$ & $\begin{array}{l}7.5760 \\
33\end{array}$ \\
\hline AGREE & 15.64629 & $\begin{array}{l}1.0296 \\
24\end{array}$ & $\begin{array}{l}4.3303 \\
79\end{array}$ & $\begin{array}{l}0.0839 \\
66\end{array}$ & -0.38877 & $\begin{array}{l}4.6500 \\
26\end{array}$ & $\begin{array}{l}- \\
0.3887 \\
7\end{array}$ & $\begin{array}{l}4.6500 \\
26\end{array}$ \\
\hline $\begin{array}{l}\text { NEUTRA } \\
\mathrm{L}\end{array}$ & -3.00801 & $\begin{array}{l}4.1576 \\
72 \\
\end{array}$ & $\begin{array}{l}- \\
0.7234 \\
8\end{array}$ & $\begin{array}{l}0.4966 \\
07 \\
\end{array}$ & -13.1815 & $\begin{array}{l}7.1654 \\
44 \\
\end{array}$ & $\begin{array}{l}- \\
13.181 \\
5\end{array}$ & $\begin{array}{l}7.1654 \\
44\end{array}$ \\
\hline
\end{tabular}


INTERNATIONAL JOURNAL OF ACADEMIC RESEARCH IN BUSINESS AND SOCIAL SCIENCES

Vol. 8, No. 5, May 2018, E-ISSN: 2222-6990 @ 2018 HRMARS

\begin{tabular}{|l|l|l|l|l|l|l|l|l|}
\hline DISAGRE & & 3.6131 & 2.0693 & 0.0049 & & 24.487 & 6.8052 & 24.487 \\
$\mathrm{E}$ & 2.130627 & 46 & 26 & 27 & 6.805242 & 34 & 42 & 34 \\
\hline
\end{tabular}

Source:Regression (OLS) 2017

From our model: $R^{2}=0.849854$, while $F(3,6)=11.32036$

No. of observations $=10$ and No. of variables $=4$

\section{Interpretation of Result}

From the analysis in table ' $v$ ' above, the interpretation of the result with regard the coefficient of various repressors and the value of the intercept which accounts for 50.3348 shows that founder's value impact positively on the turnover intention of small and medium scale enterprise up to $50.3348 \%$ when other variables are held constant. The estimate coefficients which account for 15.64629 \{AGREE\} shows that founder's value impact on the turnover intention of small and medium scale enterprise which account for $15.65 \%$ when other variables are held constant while the response for NEUTRAL and DISAGREE account for -3.00801 and 2.130627 respectively.

\section{Statistical Criteria \{First Order Test}

Coefficient of Multiple Determinants $\left\{R^{2}\right\}$ : The $R^{2}\{R$-Squared $\}$ which measures the overall goodness of fit of the entire regression, shows the value as 0.849854 i.e $84.9854 \%$ approximately $85 \%$. This indicates that the independent variables accounts for about $85 \%$ of the variation in the dependent variable.

\section{The Student's T-Test}

The test is carried out, to check for the individual significance of the variables. Statistically, the t-statistics of the variables under consideration is interpreted based on the following statement of hypothesis.

HO: The individual parameters are not significant.

$\mathrm{H1}$ : The individual parameters are significant.

HO. Founder's value has no effect on the turnover intention of small and medium scale enterprise

H1. Founder's value has effect on the turnover intention of small and medium scale enterprise

\section{Decision Rule}

If $\mathrm{t}$-calculated $>\mathrm{t}$-tabulated, we reject the null hypothesis $\{\mathrm{HO}\}$ and accept the alternative hypothesis $\{\mathrm{H} 1\}$, and if otherwise, we select the null hypothesis $\{\mathrm{HO}\}$ and reject the alternative hypothesis $\{H 1\}$. Level of significance $=\alpha$ at $5 \%=\frac{0.05}{2}=0.025$. Degree of freedom: $n-k$, where $n$ : sample size, K: Number of parameter. Then 10-4 = 6 
INTERNATIONAL JOURNAL OF ACADEMIC RESEARCH IN BUSINESS AND SOCIAL SCIENCES

Vol. 8, No. 5, May 2018, E-ISSN: 2222-6990 @ 2018 HRMARS

Table vi: Summary of the t-test analysis result:

\begin{tabular}{|l|l|l|}
\hline $\begin{array}{l}\text { Variables } \\
\text { t- } \\
\text { calculated }\}\end{array}$ & t-tab & Remark \\
\hline $\begin{array}{l}\text { AGREE } \\
\{4.330379\}\end{array}$ & \pm & Significant \\
\hline $\begin{array}{l}\text { NEUTRAL } \\
\{-0.72348\}\end{array}$ & \pm 2. & Insignificant \\
\hline $\begin{array}{l}\text { DISAGREE } \\
\{2.069326\}\end{array}$ & \pm 2. & Insignificant \\
\hline
\end{tabular}

Source:Regression (OLS) 2017

The t-statistics is used to test for individual significance of the estimated parameters $\{\beta 1, \beta 2$, and $\beta 3\}$. From the table above, we can deduce that the parameter agreed has $\{4.330379\}$ is greater than 2.447 which represents the t-tabulated implying that the parameter agreed is statistically significant. On the other hand, NEUTRAL $\{-0.72348\}$ and DISAGREE $\{2.069326\}$ are less than the t-tabulated $\{2.447\}$ signifying that they are all statistically insignificant.

\section{F-Test}

The F-Test is used to test for simultaneous significance of all the estimated parameters. The hypothesis is stated:

$\mathrm{HO}: \beta 1=\beta 2=\beta 3$

$H 1: \beta 1 \neq \beta 2 \neq \beta 3$

Level of significance: $\alpha$ at $5 \%$

Degree of freedom: $\frac{K-1}{N-K}$

\section{Decision Rule}

If the $f$-calculated is greater than the $f$-tabulated $\{f$-cal $>f$-tab $\}$ reject the null hypothesis $\{\mathrm{H} 0\}$ that the overall estimate is not significant and conclude that the overall estimate is statistically significant. From the result, $\mathrm{f}$-calculated $\{11.32036\}$ is greater that the $\mathrm{f}$-tabulated $\{6.2272\}$, that is, $f$-cal $>\mathrm{f}$-tab. Hence, we reject the null hypothesis $\{\mathrm{HO}\}$ that the overall estimate has a good fit which implies that Founder's value has positive impact on the turnover intention of small and medium scale enterprise. 
INTERNATIONAL JOURNAL OF ACADEMIC RESEARCH IN BUSINESS AND SOCIAL SCIENCES

Vol. 8, No. 5, May 2018, E-ISSN: 2222-6990 ㄷ 2018 HRMARS

\section{Test of Hypothesis 2}

Socialization exhibits positive influence on the employee turnover intentions in South-east

Nigeria SMEs.

Table vii: SUMMARY OUTPUT

\begin{tabular}{|l|l|}
\hline \multicolumn{2}{|l|}{ Regression Statistics } \\
\hline Multiple R & 0.761904 \\
\hline R Square & 0.780498 \\
\hline $\begin{array}{l}\text { Adjusted R } \\
\text { Square }\end{array}$ & 0.370747 \\
\hline Standard Error & 30.73628 \\
\hline Observations & 10 \\
\hline
\end{tabular}

ANOVA

\begin{tabular}{|c|c|c|c|c|c|c|c|c|}
\hline & & $D f$ & SS & MS & $F$ & $\begin{array}{l}\text { Significance } \\
F\end{array}$ & & \\
\hline \multicolumn{2}{|l|}{ Regression } & 3 & 7843.688 & 2614.563 & 2.767557 & 9.133469 & & \\
\hline \multicolumn{2}{|l|}{ Residual } & 6 & 5668.312 & 944.7187 & & & & \\
\hline \multicolumn{2}{|l|}{ Total } & 9 & 13512 & & & & & \\
\hline & Coefficients & $\begin{array}{l}\text { Standard } \\
\text { Error }\end{array}$ & t Stat & P-value & $\begin{array}{l}\text { Lower } \\
95 \%\end{array}$ & Upper 95\% & $\begin{array}{l}\text { Lower } \\
95.0 \% \\
\end{array}$ & $\begin{array}{l}\text { Upper } \\
95.0 \%\end{array}$ \\
\hline Intercept & 44.24476 & 42.42163 & 3.042976 & 0.337148 & -59.5572 & 148.0468 & $\begin{array}{l}- \\
59.5572\end{array}$ & 148.0468 \\
\hline AGREE & 6.836233 & 2.322593 & 2.640195 & 0.300752 & -8.31287 & 3.053495 & $\begin{array}{l}- \\
8.31287\end{array}$ & 3.053495 \\
\hline NEUTRAL & 6.557963 & 5.207316 & 1.259375 & 0.254669 & -6.18388 & 19.29981 & $\begin{array}{l}- \\
6.18388\end{array}$ & 19.29981 \\
\hline DISAGREE & -2.62969 & 5.100926 & -1.13222 & 0.2287 & -5.64528 & 19.31775 & $\begin{array}{l}- \\
5.64528\end{array}$ & 19.31775 \\
\hline
\end{tabular}

Source:Regression (OLS) 2017

From the above model: $R^{2}=0.780498$, while $F(3,6)=9.133469$

No. of observations $=10$, and No. of variables $=4$

\section{Interpretation of Result}

From the above analysis in tables vii, the value of the intercept which is 44.24476 shows that socialization effect on the turnover intention of small and medium scale enterprises up to 44.24476\%. The estimate coefficients which are 6.836233 \{AGREE\} shows that socialization effect on the turnover intention of small and medium scale enterprises which account for $6.836233 \%$ while the response for NEUTRAL and DISAGREE account for 6.557963 and -2.62969respectively. 
INTERNATIONAL JOURNAL OF ACADEMIC RESEARCH IN BUSINESS AND SOCIAL SCIENCES

Vol. 8, No. 5, May 2018, E-ISSN: 2222-6990 ㄷ 2018 HRMARS

\section{Statistical Criteria \{First Order Test}

Coefficient of Multiple Determinants $\left\{R^{2}\right\}$ : The $R^{2}$ \{R-Squared\} which measures the overall goodness of fit of the entire regression, shows the value as 0.780498 i.e. $78.0498 \%$ approximately $78 \%$. This indicates that the independent variables accounts for about $78 \%$ of the variation in the dependent variable.

\section{The student's t-test}

The test is carried out, to check for the individual significance of the variables. Statistically, the t-statistics of the variables under consideration is interpreted based on the following statement of hypothesis.

$\mathrm{HO}$ : The individual parameters are not significant.

H1: The individual parameters are significant.

HO. Socialization does not have effect on the Turnover Intention of Small and Medium Scale Enterprises.

H1. Socialization has effect on the Turnover Intention of Small and Medium Scale Enterprises

\section{Decision Rule}

If t-calculated > t-tabulated, we reject the null hypothesis $\{\mathrm{HO}\}$ and accept the alternative hypothesis $\{H 1\}$, and if otherwise, we select the null hypothesis $\{\mathrm{HO}\}$ and reject the alternative hypothesis $\{\mathrm{H} 1\}$.

Level of significance $=\alpha$ at $5 \%=\frac{0.05}{2}=0.025$. the degree of freedom: $n-k$ Where $n$ : sample size and K: Number of parameter. Then 10-4 = 6

Table viii: Summary of the t-test analysis result:

\begin{tabular}{|l|l|l|}
\hline Variables $\{$ t-calculated $\}$ & t-tab & Remark \\
\hline AGREE $\{2.640195\}$ & \pm 2.447 & Significant \\
\hline NEUTRAL $\{1.259375\}$ & \pm 2.447 & Insignificant \\
\hline DISAGREE $\{-1.1322\}$ & \pm 2.447 & Insignificant \\
\hline
\end{tabular}

Source:Regression (OLS) 2017

The $t$-statistics is used to test for individual significance of the estimated parameters $\{\beta 1, \beta 2$, and $\beta 3$ \}. From the table above, we can deduce that the parameter intercept has $\{3.042976\}$, AGREED $\{2.640195\}$, are greater than the t-tabulated $\{2.447\}$ signifying that they are statistically significant while NEUTRAL $\{1.259375\}$ and DISAGREE $\{-1.1322\}$ are less than the t-tabulated $\{2.447\}$ signifying that they are statistically insignificant.

\section{F-Test}

The F-Test is used to test for simultaneous significance of all the estimated parameters.

The hypothesis is stated;

$\mathrm{HO}: \beta 1=\beta 2=\beta 3$

$H 1: \beta 1 \neq \beta 2 \neq \beta 3$

Level of significance: $\alpha$ at $5 \%$

Degree of freedom: $\frac{K-1}{N-K}$ 
INTERNATIONAL JOURNAL OF ACADEMIC RESEARCH IN BUSINESS AND SOCIAL SCIENCES

Vol. 8, No. 5, May 2018, E-ISSN: 2222-6990 @ 2018 HRMARS

\section{Decision Rule}

If the $f$-calculated is greater than the $f$-tabulated $\{f$-cal $>f$-tab $\}$ reject the null hypothesis $\{\mathrm{H} 0\}$ that the overall estimate is not significant and conclude that the overall estimate is statistically significant. From the result, $\mathrm{f}$-calculated $\{9.133469\}$ is greater that the $\mathrm{f}$-tabulated $\{6.2272\}$, that is, $\mathrm{f}$-cal> f-tab. Hence, we accept Alterative hypothesis $\{\mathrm{H} 1\}$ and Reject null Hypothesis $(\mathrm{HO})$ which implies that Socialization have positive impact on the Turnover Intention of Small and Medium Scale Enterprises.

\section{Test of Hypothesis}

Morale has significant positive effect on the turnover intentions of SMEs in South-east Nigeria SMES

Table ix: SUMMARY OUTPUT

\begin{tabular}{|l|l|}
\hline \multicolumn{2}{|l|}{ Regression Statistics } \\
\hline Multiple R & 0.638095 \\
\hline R Square & 0.407166 \\
\hline $\begin{array}{l}\text { Adjusted R } \\
\text { Square }\end{array}$ & 0.110749 \\
\hline Standard Error & 39.42602 \\
\hline Observations & 10 \\
\hline
\end{tabular}

ANOVA

\begin{tabular}{|c|c|c|c|c|c|c|c|c|}
\hline & $\begin{array}{l}\text { Coefficient } \\
\mathrm{s}\end{array}$ & $\begin{array}{l}\text { Standard } \\
\text { Error }\end{array}$ & t Stat & P-value & $\begin{array}{l}\text { Lower } \\
95 \%\end{array}$ & $\begin{array}{l}\text { Upper } \\
95 \%\end{array}$ & $\begin{array}{l}\text { Lower } \\
95.0 \%\end{array}$ & $\begin{array}{l}\text { Upper } \\
95.0 \%\end{array}$ \\
\hline Intercept & -26.1505 & 45.50721 & -0.57464 & $\begin{array}{l}0.58641 \\
6\end{array}$ & $\begin{array}{l}- \\
137.503\end{array}$ & 85.20165 & $\begin{array}{l}- \\
137.50 \\
3\end{array}$ & $\begin{array}{l}85.2016 \\
5\end{array}$ \\
\hline AGREE & 1.225716 & 1.948025 & 0.62921 & 0.5524 & $\begin{array}{l}- \\
3.54093\end{array}$ & 5.992362 & $\begin{array}{l}- \\
3.5409 \\
3\end{array}$ & $\begin{array}{l}5.99236 \\
2\end{array}$ \\
\hline NEUTRAL & 7.895734 & 7.851299 & 1.00566 & $\begin{array}{l}0.35339 \\
9\end{array}$ & $\begin{array}{l}- \\
11.3157\end{array}$ & 27.10717 & $\begin{array}{l}- \\
11.315 \\
7\end{array}$ & $\begin{array}{l}27.1071 \\
7\end{array}$ \\
\hline \multirow[t]{2}{*}{$\begin{array}{l}\text { DISAGRE } \\
\text { E }\end{array}$} & 3.343086 & 6.111026 & $\begin{array}{l}0.54705 \\
8\end{array}$ & $\begin{array}{l}0.60407 \\
4\end{array}$ & $\begin{array}{l}- \\
11.6101\end{array}$ & 18.29623 & $\begin{array}{l}- \\
11.610 \\
1\end{array}$ & $\begin{array}{l}18.2962 \\
3\end{array}$ \\
\hline & $\begin{array}{l}\text { Coefficient } \\
\mathrm{s}\end{array}$ & $\begin{array}{l}\text { Standard } \\
\text { Error }\end{array}$ & t Stat & P-value & $\begin{array}{l}\text { Lower } \\
95 \%\end{array}$ & $\begin{array}{l}\text { Upper } \\
95 \%\end{array}$ & $\begin{array}{l}\text { Lower } \\
95.0 \%\end{array}$ & $\begin{array}{l}\text { Upper } \\
95.0 \%\end{array}$ \\
\hline Intercept & -26.1505 & 45.50721 & -0.57464 & $\begin{array}{l}0.58641 \\
6\end{array}$ & $\begin{array}{l}- \\
137.503\end{array}$ & 85.20165 & $\begin{array}{l}- \\
137.50 \\
3\end{array}$ & $\begin{array}{l}85.2016 \\
5\end{array}$ \\
\hline
\end{tabular}


INTERNATIONAL JOURNAL OF ACADEMIC RESEARCH IN BUSINESS AND SOCIAL SCIENCES Vol. 8, No. 5, May 2018, E-ISSN: 2222-6990@ 2018 HRMARS

\begin{tabular}{|c|c|c|c|c|c|c|c|c|}
\hline AGREE & 1.225716 & 1.948025 & 0.62921 & 0.5524 & $\begin{array}{l}- \\
3.54093\end{array}$ & 5.992362 & $\begin{array}{l}- \\
3.5409 \\
3\end{array}$ & $\begin{array}{l}5.99236 \\
2\end{array}$ \\
\hline NEUTRAL & 7.895734 & 7.851299 & 1.00566 & $\begin{array}{l}0.35339 \\
9\end{array}$ & $\begin{array}{l}- \\
11.3157\end{array}$ & 27.10717 & $\begin{array}{l}- \\
11.315 \\
7\end{array}$ & $\begin{array}{l}27.1071 \\
7\end{array}$ \\
\hline $\begin{array}{l}\text { DISAGRE } \\
\text { E }\end{array}$ & 3.343086 & 6.111026 & $\begin{array}{l}0.54705 \\
8\end{array}$ & $\begin{array}{l}0.60407 \\
4\end{array}$ & $\begin{array}{l}- \\
11.6101\end{array}$ & 18.29623 & $\begin{array}{l}- \\
11.610 \\
1\end{array}$ & $\begin{array}{l}18.2962 \\
3\end{array}$ \\
\hline
\end{tabular}

Source:Regression (OLS) 2017

From our model: $\mathrm{R}^{2}=0.407166$ while $\mathrm{F}(3,6)=0.337944$

No. of observations $=10$, and No. of variables $=4$

\section{Interpretation of Result}

From the above analysis in tables ix, the value of the intercept which is -26.1505 shows that effect of morals on turnover intention of small and Medium Scale Enterprises accounts to $-26.1505 \%$ .The estimate coefficients which accounts for 1.225716 \{AGREE\} shows that socialization effect on the turnover intention of small and medium scale enterprises account for $2.62969 \%$ when other variables held constant while the response for NEUTRAL and DISAGREE account for $7.895734 \%$ and $3.343086 \%$ respectively when other variables are held constant.

\section{Statistical Criteria \{First Order Test}

Coefficient of Multiple Determinants $\left\{R^{2}\right\}$ : The $R^{2}$ \{R-Squared\} which measures the overall goodness of fit of the entire regression, shows the value as 0.407166 i.e. $40.7166 \%$ approximately $41 \%$. This indicates that the independent variables accounts for about $41 \%$ of the variation in the dependent variable. This shows that there is weak relationship among variables.

\section{The student's t-test}

The test is carried out, to check for the individual significance of the variables. Statistically, the tstatistics of the variables under consideration is interpreted based on the following statement of hypothesis.

HO: The individual parameters are not significant.

$\mathrm{H} 1$ : The individual parameters are significant.

HO. Socialization does not have effect on the Turnover Intention of Small and Medium Scale Enterprises

H1. Socialization has effect on the Turnover Intention of Small and Medium Scale Enterprises

\section{Decision Rule}

If $\mathrm{t}$-calculated $>\mathrm{t}$-tabulated, we reject the null hypothesis $\{\mathrm{HO}\}$ and accept the alternative hypothesis $\{\mathrm{H} 1\}$, and if otherwise, we select the null hypothesis $\{\mathrm{HO}\}$ and reject the alternative hypothesis $\{\mathrm{H} 1\}$. 
INTERNATIONAL JOURNAL OF ACADEMIC RESEARCH IN BUSINESS AND SOCIAL SCIENCES

Vol. 8, No. 5, May 2018, E-ISSN: 2222-6990 @ 2018 HRMARS

Level of significance $=\alpha$ at $5 \%=\frac{0.05}{2}=0.025$. Degree of freedom: $n-k$ where $n$ : sample size and $\mathrm{K}$ : Number of parameter. Then 10-4 = 6

Tables $\mathrm{x}$ : Summary of the t-test analysis result:

\begin{tabular}{|l|l|l|}
\hline Variables $\{$ t-calculated $\}$ & t-tab & Remark \\
\hline AGREE $\{1.225716\}$ & \pm 2.447 & Significant \\
\hline NEUTRAL $\{7.895734\}$ & \pm 2.447 & Significant \\
\hline DISAGREE $\{3.343086\}$ & \pm 2.447 & significant \\
\hline
\end{tabular}

Source:Regression (OLS) 2017

The t-statistics is used to test for individual significance of the estimated parameters $\{\beta 1, \beta 2$, and $\beta 3\}$. From the table above, we can deduce that the parameter intercept has $\{-0.57464\}$, AGREED $\{1.225716\}$, are less than the t-tabulated $\{2.447\}$ signifying that they are all statistically insignificant. On the other hand NEUTRAL $\{7.895734\}$ and DISAGREE $\{3.343086\}$ are greater than the t-tabulated $\{2.447\}$ signifying that they are all statistically significant.

\section{F-Test}

The F-Test is used to test for simultaneous significance of all the estimated parameters.

\section{The hypothesis is stated}

$\mathrm{HO}: \beta 1=\beta 2=\beta 3$

$H 1: \beta 1 \neq \beta 2 \neq \beta 3$

Level of significance: $\alpha$ at $5 \%$

Degree of freedom: $\frac{K-1}{N-K}$

\section{Decision Rule}

If the $f$-calculated is greater than the $f$-tabulated $\{f$-cal $>f$-tab $\}$ reject the null hypothesis $\{\mathrm{H} 0\}$ that the overall estimate is not significant and conclude that the overall estimate is statistically significant. From the result, $\mathrm{f}$-calculated $\{0.337944\}$ is less than the $\mathrm{f}$-tabulated $\{6.2272\}$, that is, $\mathrm{f}$-cal $<\mathrm{f}$-tab. Hence, we accept the null hypothesis $\{\mathrm{HO}\}$ and Reject Alternative Hypothesis which implies that morals have no effect on turnover intention of SMEs.

\section{Discussion of Findings}

Discussion of findings on Founders values and turnover intention of small and medium enterprises.

From the result, it implies that Founder's value has positive impact on the turnover intention of SMEs. $\chi^{2}(95, n=330)=11.32036, p<0.05$. Chu and Chieh (2016) in the literature review explains how corporate ethical values influence turnover intention based on social identity theory and ethical principled theory. The empirical results observed that career satisfaction directly relates to turnover intention whereas corporate ethical values indirectly relate to turnover intention through the full mediation of organizational identification. Meanwhile, the effects of career 
satisfaction on turnover intention and on organizational identification are positively moderated by corporate ethical values.

\section{Discussion of findings on Socialization and turnover intention of SMEs}

From the result, it implies that Socialization have positive impact on the Turnover Intention of SMEs. $\chi^{2}(95, n=330)=9.133469, p<0.05$. Mariam and Hummayoun (2011) noted that organizational socialization enhances organizational commitment of employees, thereby reducing the cost of losing employees. Therefore, socialization program must be designed in a way that fulfils the expectation of employees. Ayesha, Qurat, Rabia, and Muhammad (2014) emphasisedthe point that Working conditions, pay and promotion, Job safety and security, Training and development and employee empowerment impact on employees' satisfaction.

\section{Discussion of findings on Morals and turnover intention of SMEs}

The test result for hypotheses three implies that morals has no effect on turnover intention of small and medium scale enterprises in south-east Nigeria. $\chi^{2}(95, n=330)=0.337944 p$ $>0.05$. Obiwuru, Okwu, Akpa and Nwankwere (2011) in support of the result argued that transactional leadership style was more appropriate in inducing performance SMEs than transformational leadership style and, therefore, recommended transactional leadership style for the small enterprises with inbuilt strategies for transition to transformational leadership style as the enterprises developed, grew and matured.

\section{Summary}

The socialization enhances organizational commitment of employees, thus reducing cost of losing employees. Therefore Socialization programmes must be designed to fulfil the expectation of employees. It helps to understand the satisfaction level of employees and how they can be motivated for improved and efficient performance. Further, this study observes an indirect impact of organizational learning culture on turnover intention when job satisfaction is considered as a mediator. Both organizational learning culture and job satisfaction have strong correlation with turnover.

\section{Recommendations}

SMEs Stakeholders should adopt managerial initiatives that promote workers' satisfaction in order to make high profit and experience growth. Workers' salaries and other allowances should be paid as and when due.

\section{Recommendations for Further Research}

Further research is recommended in the areas of pro-workers' policies in SMEs, and the fundamental limitations to addressing their individual requirements for effective discharging of their official duties.

\section{Acknowledgments}

We acknowledge all the authors whose works were referred to, reviewed, and quoted in the course of this research. The research is a self-funded project. Thus we are not obliged to acknowledge any organisation, institution or body. 
INTERNATIONAL JOURNAL OF ACADEMIC RESEARCH IN BUSINESS AND SOCIAL SCIENCES

Vol. 8, No. 5, May 2018, E-ISSN: 2222-6990 @ 2018 HRMARS

\section{Corresponding Author}

Mbah, Paulinus Chigozie

Department of Business Administration,

Faculty of Management Sciences,

Enugu State University of Science and Technology (ESUT), Enugu, Nigeria.

Email: godblesspaulinus@yahoo.com

\section{References}

Alvesson, H. (2002). Understanding Organizational Culture. London: SAGE Publications. ISBN 07619-7005-3

Ayesha, M., Qurat, U. A., Rabia, A., and Muhammad, R. (2014). Factors Affecting Employee Satisfaction of the Public and Private Sector Organizations of Pakistan. International Journal of Human Resource Studies, 4(2): 97- 121

Ayyagari, M., Demirguc-Kunt, A., and Maksimovic, V. (2011). Small vs. Young Firms across the World: contribution to employment, job creation, and growth. Policy Research Working Paper Series, 5631

Ayyagari, M., Beck, T., and Demirgüç-Kunt, A. (2007). Small and medium enterprises across the globe.Small Business Economics, 29(4): 415-434

Cascio, W. F. (2006). Managing Human Resources: Productivity, Quality of Life and Projects. Meggraw-Hill Irwin

Chu, M. L., and Chieh, P. L. (2016) Corporate Ethical Values and Turnover Intention, Journal of Leadership and Organizational Studies. 103, 411-423

Ezigbo, C. A. (2011). Advanced Management: Theory and Applications. Enugu, Immaculate Publication Ltd. Gibson, and Van der Vaart, 2008

Gonzales, E. (2013). SMEs in Relation to Poverty, Employment, and Productivity: Setting the Way Forward. Literature Review Paper, Internal Report. Washington, DC: Inter-American Development Bank

Hurst, E., and Pugsley, B. W. (2011). What Do Small Businesses Do? National Bureau of Economic Research Working Paper Series, 17041

Kunda, G., and Van Maanen, J. (1989). "Real feelings": Emotional expression and organizational culture, Research in Organizational Behavior, 11: 43-103

Kushnir, K., Mirmulstein, M., and Ramalho, R. (2010). Micro, Small, and Medium Enterprises around the World: How Many AreThere, and What Affects the Count? IFCMSME Country Indicators. Washington, DC: The World BankMariam and Hummayoun (2011

Mariam, M., and Hummayoun, N. (2011). Relationship of organization socialization with organizational commitment and turnover intention: Moderating role of Perceived Organizational Support. Interdisciplinary Journal of Contemporary Research in Business, 3(8): 515

Mello, J. A. (2011). Strategic Human Resource Management. 3rd Ed, OH: South-western Cengage Learning Michael 1986

Michaele, C. (2017). Turnover Intention.Downloaded 23/3/2018 from http://smallbusiness.chron. com/turnover-intention-12753.html 
Miliaras, C. (2012). Creating jobs that reduce poverty: A research agenda on developing-country gazelles.RTI Press publication, OP-0011-1211. Research Triangle Park, NC: RTI Press. Downloaded on 23/3/2018 from http:// www.rti.org/rtipress

Muzainah, M., and Mahamad, T. (2010): An empirical examination of organizational culture, job stress and job satisfaction within the Indirect Tax Administration in Malaysia.

Nazneen, A., and Bhalla, P. (2014) A study of ORS and among the Faculty members of Private and Public University. International Journal of Human Resource Management and Research, 3(4): 17-25

Obiwuru, T. C., Okwu, A. T., Akpa, V. O., and Nwankwere, I. A. (2011). Effects of leadership style on organizational performance: a survey of selected small scale enterprises in Ikosi-Ketu council development area of Lagos State, Nigeria

OECD. (2004). PromotingEntrepreneurship and Innovative SMEs in a Global Economy: Towards a More Responsible and Inclusive Globalisation.OECD Conference of Ministers Responsible for Small and Medium-sized Enterprises (SMEs). Istanbul, Turkey

Qazi, S., Miralam, Saleh, M., and Bhalla, P. (2017) Organizational culture and job satisfaction: a study of organized retail sector. Journal of Business and Retail Management Research (JBRMR), Vol. 12 Issue 1 October 2017: 215 - 224. Downloaded on 12/03/2018 from www.jbrmr.com

Raheleh, E., Ebrahim, M., Durrishah, I., Dhaifallah, O. A. (2012). Investigating the Relationship between Organizational Learning Culture, Job Satisfaction and Turnover Intention in it SMEs.International Journal of Innovative Ideas, 12(1): 8-23

Sabri, P. S. U., Ilyas, M., and Amjad, Z. (2011). Organizational Culture and Its Impact on the Job Satisfaction of the University Teachers of Lahore.International Journal of Business and Social Science, 2(24), pp. 121-128

Schein, E. H. (1984). Coming to a New Awareness of Organizational Culture.Sloan Management Review, 25:2-3

Schein, E. H. (2010). Organizational Culture and Leadership. San Francisco, CA: Jossey-Bass Publishers. ISBN: 1-55542-487-2.Shah (2011

Shah, S. M., Memon, S. M., and Laghari, M. K. (2011). The impact of organizational culture on employees Satisfaction: A study of faculty members of public sector universities of Pakistan.Interdisciplinary Journal of Contemporary Research in Business,3(8): 847-859

Stein, P., Goland, T., and Schiff, R. (2010). Two trillion and counting.Access to Finance. Washington, DC: The World Bank

Swati, M. (2016).Effects of transformational leadership on turnover intentions in IT SMEs.International Journal of Manpower, 37(8): 1322-1346

Tsai, Y. (2011). Relationship between Organizational Culture, Leadership Behaviour and Job Satisfaction.BMC Health Services Research, 11: 83-105 